\title{
The Potential of Online Technology for Language Learning
}

\author{
Shuang Zeng ${ }^{1}$ \\ ${ }^{1}$ College of Foreign Languages, University of Shanghai for Science and Technology \\ Correspondence: Shuang Zeng, College of Foreign Languages, University of Shanghai for Science and \\ Technology, Shanghai, China. E-mail: s.zeng@usst.edu.cn
}

Received: August 11, 2020

Accepted: August 27, 2020

Online Published: September 2, 2020

doi: 10.5539/elt.v13n10p23

URL: https://doi.org/10.5539/elt.v13n10p23

\begin{abstract}
This paper concerns language learning with online technologies, with a particular focus on the influence of the social web on language learning. In particular, this paper considers the discourses of web-assisted language learning in detail, and argues the necessity of investigating its 'new' affordances from a perspective that is more learner-centered, contextualized and language learning focused. This paper reviewed the relatively long history of using pre- 'Web 2.0' technologies and identified the ways in which these applications have been perceived to enhance language learning. This paper enables us to think more clearly about the 'novelties' that are associated with online technologies in language learning contexts.
\end{abstract}

Keywords: Online technology; Social web, Web 2.0, language learning, CALL

\section{Introduction: Insights from CALL Literature between 1960-2000}

The history of computer-assisted language learning (CALL) has been accompanied by the corresponding development in educational methodology and technology. Accordingly, Warschauer and Healey (1998) have proposed to divide CALL history into three salient phases: from behaviouristic notion of CALL 1960s and 1970s, via communicative notions of CALL in late 1970s and early 1980s, to integrative notions of CALL since late 1980s (Warschauer \& Healey, 1998; Kern \& Warschauer, 2000).

The behaviouristic CALL was primarily informed by the work of Skinner $(1954,1957)$, who conceptualized learning as a process of habit-formation. Thus this mode of CALL attached great importance to the 'drill-and-practice' exercises, where a second language was acquired through imitation and repetition (Levy, 1997). Computers here were seen as 'mechanical tutors' through which language learners were provided with structured practices and responses (Warschauer \& Healy, 1998). A well-known paradigm in this case was the PLATO (Programmed Logic for Automatic Teaching Operations) Project initiated in 1960s. PLATO was designed to provide a large number of university language learners with extensive drill practices, evaluations and self-paced grammatical explanations (Smith \& Sherwood, 1976; Ahmad et al., 1985). This project was seen to be a milestone in CALL history as it connected, for the first time, the language instructors and technologists worked together in developing the CALL materials (Salaberry, 2000).

The communicative CALL emerged when behaviourist approach to SLA was beginning to be disputed and Communicative Language Teaching (CLT) was embraced at both theoretical and pedagogical level (Levy, 1997). The perceived goal of language learning at that time was no longer limited to the acquisition of linguistic forms but to express oneself effectively and appropriately during conversational exchanges with native or expert speakers of the target language. Theorists therefore began to pay attention to the weight of learner attributes and needs during the process of SLA. In the meanwhile, the advent of micro/personal computer was creating greater opportunities for learners and teachers to work individually or in small groups. CALL at this stage corresponded to the technical advancement and the pedagogical shift towards a more communicative approach to SLA — with the computer technology allowing language learners, working alone or collaborating in groups, to explore the linguistic forms of the target language; one of the main focuses during this period was to use the technology to encourage the original utterances of language learners (Warschauer \& Healy, 1998). As learners obtained more freedom in the learning process, it seemed change was occurring in the role of computers within language learning and teaching. Instead of delivering prefabricated knowledge and drill exercises, computers became more like a tool for discovery, expression and development. A typical example of communicative CALL was the 
Storyboard program, in which the authorized teachers and students were allowed to, within a closed system, rewrite a text or construct their own texts for future use (Levy, 1997).

By the end of 1980s, however, a more circumspect focus emerged then reflected the practices of communicative CALL and their impacts on the language learning process (Warschuauer \& Healey, 1998). Alongside the argument that "the majority CALL uses were limited, in form, to drill and practice exercises", much criticism too was based on the pedagogical and technological developments at that time (Liu et al., 1999, p., 3). Notable amongst the pedagogical trends that began to appear in the late 1980s was the highlight of the "authentic environment' for language learning. This corresponded to the shift in learning paradigm from CLT to a more socio-cognitive perspective. Another driver of these changes was, undoubtedly, the Internet. Major breakthroughs included the introduction of software for information location and retrieval, the release of the World Wide Web system (web 1.0), and a capacity for accommodating multimedia materials (Levy, 1997). As a result, the Internet fostered greater possibility to access people, authentic language learning materials and environments. Accordingly, CALL was said to enter an integrative phase, in which tasks often sought to "integrate learners in authentic environments, and also to integrate the various skills of language learning and use" (Warschuauer \& Healey, 1998, p., 58; Warschauer, 1996).

It is perhaps important to recognize that this liner account of the CALL development is not without disagreement. For example, Bax (2003) challenged this often-quoted historical analysis, arguing that the core parts of so-called integrative approach were not new to communicative CALL in terms of their shared emphases on original expressions and the task-based approaches (Bax, 2003). Yet despite of inconsistency over taxonomies, few commentators would argue that CALL in 1990s was an advance over that of in 1980s, particularly with its increased accessibility to learning resources and online environment enriched via audio, video and graphs (Liu et al., 1999). One of the large-scale CALL projects in 1990s was the International Email Tandem Network. Participants of this project were able to exchange advices via email or forum, and easily access and add learning resources to the database (Levy, 1997).

By the end of 1990s, a significant amount of literature had explored and discussed the potentials of technology for second language teaching and learning (Liu, et al., 1999). Given what appeared in the literature, a useful way of considering how CALL has helped support the SLA process, according to Chapelle (2003), is to "work with small unit of analysis" (p., 40). Thus this paper analyzes CALL based on the SLA components identified by Ellis (1997), particularly the use and manipulation of learning resources, opportunities for language use, the social interaction CALL facilitates, the learning environment it provides and how it caters to individual needs and interests. Nevertheless, it is worth noting that identified facets are somehow interrelated, both within and across their respective categories. Thus a separate discussion of these notions does not aim to segment the acquisition process. Rather, it attempts to provide varied and balanced accounts of CALL activities from different pedagogic focuses, thereby resulting in a holistic picture of how technologies have been perceived to accommodate the components that shape the SLA process, thus language learning in general.

\subsection{Input}

A central concept across different approaches to SLA is that language learners have the opportunity to acquire the linguistic features of the target language. This essential prerequisite to SLA was naturally aligned with the World Wide Web's functionality to "placing an unprecedented amount of information at the hands of individual users all around the globe" (Warschauer, 1999, p. 7). In fact, CALL tasks concerned with WWW can be said to enhance the input component in at least three aspects. First, WWW was seen to have significantly increased the accessibility and exposure of input resources, whether in formal or self-study settings (Zhao, 2003). Particularly learning materials in the form of visual, audio and textual were brought together and made available on the web. Language learners could access these resources at their fingertips through online search engines.

Additionally, the web was said to accumulate primary source of information in different languages, and therefore privileged language learners with authentic foreign language input. After all, the definition of 'authentic' is often used to describe the information created for communicative or social purposes, rather than for educational agendas (Coleman, 2000). Finally, CALL was said to give language learners the freedom to work with input in a controllable manner (Hoven, 1999). In this sense, learners were allowed to select their learning materials and consume them at their own pace.

\subsection{Output}

The use of CALL, and CMC in particular for new options of learner output had already been documented in literature. Applications exemplified by Bulletin Board System (BBS), e-mail, and chatrooms had been found to offer computer-enhanced opportunities for learner productions in writing or in speech or in a combination of 
both (Salaberry, 2001; Sheaffer-Jones, 2000; Kelm, 1998; Beauvois, 1997; Pennington, 1996). One of the benefits cited for computerised outputs was that language learners were granted the planning time when producing the target language. This was because planning was conducive to the cognitive efforts on the part of learners to produce grammatically correct language (Chapelle, 2003). The time allowance was also said to relieve the pressure of language producers, mainly because output could be constructed at their own pace and physical convenience, and that preparation was made possible via consulting authoritative resources, self-correction, or seeking help from others (Ullrich, et al., 2008). But the value of planning, at least from the cognitive dimension, was not always evident in CMC practices at this stage, as they often endeavour to facilitate informal and personal exchanges (Chapelle, 2003).

$\mathrm{CMC}$ was also said to promote learner participation and motivation, and foster the possibilities for negotiation, as a result of which leads to considerable amounts of learner production (Sheaffer-Jones, 2000; Pellettieri, 2000; Beauvois, 1997). Nevertheless, the generation of linguistic output was not limited to CMC activities. A number of computer programs and software, ranging from early drill exercises to communicative interactions with the computer, had created new opportunities for language learners to use the target language in various settings (Kelm, 1998; Kern \& Warschauer, 2000). For example, speech synpaper technologies allowed learners to select topics and accordingly converse with the computer in a simulated environment (Egan, 1999; LaRocca, et al., 1999; Holland et al., 1999).

\subsection{Interaction}

CALL was said to have signaled an approach to second language learning in which interaction can empower the learner. The associations between the various forms of computerized interactions and SLA had been conceptualized and expounded mainly from the theoretical positions listed in Table 1.

Table 1. Benefits of three types of interaction from three perspectives (Chapelle, 2003, p., 56)

\begin{tabular}{ccccc}
\hline \multirow{2}{*}{ Basic types of interaction } & & \multicolumn{2}{c}{ Perspectives on the value of interaction } \\
\cline { 3 - 5 } & Interaction hypopaper & Socio-cultural theory & Depth of processing theory \\
\hline Inter- & $\begin{array}{c}\text { Between people } \\
\text { Between people } \\
\text { and computer } \\
\text { Within the } \\
\text { person's mind }\end{array}$ & Negotiation of meaning & Co-construction of meaning & Prompting attention to language \\
Intra- & Attending to linguistic form & Stimulating internal mental voice & Cognitive processing of input \\
\hline
\end{tabular}

It was noted that educators and practitioners in the 1990s were especially interested in the interpersonal interactions afforded by technology (Liu et al., 2000). This included the automatic and personalized feedback provided by computers, and the technology-induced capacity of students to communicate with remote audiences and those whom shared the computer (Chapelle, 2003). In particular, technologies exemplified by grammar and spelling checkers were said to enhance the written outputs, forming an interactive pattern between the learner and computer. Moreover, social interactions sometimes occurred among learners who were striving to accomplish a CALL task using the same computer. In this case, "the focus was not so much on what students did with the machine, but rather what they with each other while working at the computer" (Warschauer \& Healey, 1998, p., 57). Last, but by no means the least, CMC technologies were often regarded as the real forte of computerized interaction and assumed to promise a profound influence in language learning.

It had been extensively discussed within CALL circles of how the nature of mediated language learning was affected by the "...communication that takes place between human beings via the instrumentality of computers" (Herring, 1996, p., 1). Comparing with face-to-face interactions, CMC was said to minimize social context clues such as gender, race and status, together with nonverbal cues of facial expressions and body languages, therefore creating a less intimidating environment for language learners. This is especially so for learners with less confidence and power (Sproull \& Kiesler, 1991; Hanson-Smith, 2001).

Additionally, Warschauer (1997) noted that CMC's feature of 'time- and place- independent communication presented language learners with communication opportunities beyond the constraints of the classroom. Moreover, the revolutionary feature of CMC to support text-based communication was believed to have unleashed new means of interaction, in which learner reflection was allowed, learner utterance was encouraged and text edition was made straightforward (Harnad, 1991; Warschauer, 1997).

Finally, the interconnectivity of CMC allowed multiple types of information exchanges: one-to-one, one-to-many and many-to-many (Harrington and Levy, 2001). It was claimed that the distinctive capability of 
CMC to facilitate language learning was best reflected in many-to-many interaction, mainly because it made possible geographically dispersed groups working towards joint language learning projects (Vilmi, 1995), and facilitated the linguistic and cultural exchanges between the groups speaking different languages (Cummins \& Sayers, 1995; Kern, 1996; Meskill \& Rangelova, 1995).

However, these seemingly advantages of CMC had attracted diverse criticism. Peyton (1999) countered that CMC could be "less interactive than interinsultive" as the sense of anonymity experienced among interlocutors had sheltered the exchange of hostile feedback (p., 23); Cunningham argued that CMC could militate against many kinds of collaborative work because it was difficult for time and space independent individuals to reach consensus in group discussion; Moran (1991) stressed CMC's problem of overwhelming learners with too much information, arguing that it resulted in not peer interactions but learner monologues because they tended to disregard the information constructed by others in the case of 'information overload'. Moreover, albeit a strong resemblance exists between online 'chatting' and spoken conversation, the exchange of text messages could, at most, indirectly help promote speaking ability when it served as a preparation for the follow-up spoken discussion, or when learners had successfully transferred the skill from 'chatting' to speaking (Payne \& Ross, 2005). In other words, it could be argued in relations to oral proficiency development that the potential benefits of $\mathrm{CMC}$ were counterbalanced by the deficiency of verbal interactions.

\subsection{CALL and the Language Learning Environment}

In the view of educators and theorists, the phrase of CALL environment might refer to either "the web of classroom, text and laboratory activities into which CALL system connects and integrates", or "the CALL system itself" (Schoelles \& Hamburger, 1996, p., 213). Yet evidence had accumulated in literature that irrespective of possible situations, CALL had the potential of creating a non-threatening yet stimulating environment for SLA (Ulitsky, 2000; Sullivan \& Pratt, 1996; Liu \& Reed, 1994; Gonzalez-Edfelt, 1990). This was because firstly, in a CALL environment learners were provided with exposure to cognitive opportunities that existed intensively in authentic input resources, tasks and projects (Spolsky, 1989). Moreover, the multimedia capabilities of CALL necessitated a renewed channel for not just the linguistic input but also a vivid demonstration of related cultural differences and contextual factors (Hoven, 1997). This was said to be in sharp contrast with the traditional classroom where had often appeared to be lacking the environment for cultural awareness (Sheaffer-Jones, 2000).

Another profound effect of CALL environment concerns its provision of potential assistants for language learning. In particular, CALL environment exposed language learners to the 'expertise' of potential audience or automatic feedback, and therefore the mechanisms involved for language learning. The last aspect of CALL environment that seemed particularly important was its support for learner control. This entailed the increased choices of learning time and locations, and of what Brennan noted "(the) continuous representation of the objects of interest... and rapid, incremental, reversible operation with immediate visual feedback" (Brennan, 1990, p., 393).

\subsection{Differentiation of Learning}

Increasingly, researchers were attempting to support the emerging concept of 'autonomy' where learners were assumed to take major responsibilities for the learning process (Cotterall, 1995; Holec, 1981). In line with this pedagogical desirability, CALL proponents pointed out that computers were better suited to catering the needs, preferences and development of individual learners (Jonassen, 1992; Lantolf \& Appel, 1994). That is, the nature of many CALL paradigms to focus on learners as individuals was seen to accord the pedagogic flow from teacher-centered to a more learner-centered approach. With CALL, in particular, learners were allowed to make choices of when, what, and how to learn based on their own proficiency levels, goals and learning styles. Moreover, this beneficial effect of CALL, together with its affordance of the time to think and the possibility for feedback, led to an atmosphere with ideal anxiety and stress level for the individual learner (Egbert \& Hanson-smith, 1999; Oxford, 1994).

\section{Towards Current Notions of CALL Practices: WELL 2.0}

So far we have reviewed the development of CALL during 1960-2000 and briefly discussed the ways in which these CALL applications are perceived to support the prominent framework of SLA. Despite some skepticism, there was clearly no shortage of 'can do' statements generated by practitioners who utterly embraced the 'empowering' and 'transformative' prospects of CALL on language acquisition and learning. As Little (2001) generalized at the beginning of the century, "Over the past two decades the introduction of self-access system has been the single most important development affecting the learning of foreign languages in universities all around the world" (p., 29). 
This wave of optimism continues to drive the development of CALL into what Davies (n.d.) claims its latest stage - web 2.0 enhanced language learning (WELL 2.0). Over the last ten years, there arises a rapid growth integrating the emerging technologies that are collectively labeled as web 2.0 into the various scenarios of SLA. For many technology enthusiasts and educators, the new trend of CALL is sustained by the 'newness' of the social web per se and the assumption that web 2.0 'fits' nicely with language teaching and learning. In particular, the interactive and participatory characteristics of web 2.0 tools and applications are said to complement the current thinking in SLA methodology, especially in light of the constructivist framework that sees learners actively building up their knowledge within communities of practices (Ruschoff, 2009). This common conviction has left many educationalists content to assume that web 2.0 technologies are unproblematic in their ability to support, enhance or even improve language in its different forms. As Sturm and his colleagues (2008) celebrated, "the promise of web 2.0 technologies is different. Their impact on the (language) learning process and the practice of teaching is truly revolutionary" (p., 368).

In this sense, much attention has been shifted to the application of the new technologies without contemplating their implications to the SLA process (Rosell-Aguilar, 2007). Moreover, discussions and studies of WELL 2.0 have often tended to concentrate on individual variables such as writing ability (Godwin-Jones, 2008), learner autonomy (Schwienhorst, 2008), discourse analysis (Myers, 2010), learner motivation (Alm, 2006) or project-based language learning. As such, multifaceted discussion reflecting how the new technologies as a whole can systematically support language learning and acquisition seems scarce. Yet, we cannot fully understand the issues relating to WELL 2.0 unless we have mindfully considered and empirically investigated the supposed links between web 2.0 technologies and language learning. With this regard, this section sets out to synthesize the existing evidence associated with WELL 2.0, and explore its possible relationships with the multiple components that have been previously identified to shape the general process of SLA.

\subsection{Inputs and WELL 2.0}

When expounding WELL 2.0's potentials for the input facet specifically, Wu and his colleagues (2009) make an interesting analogy between the current web and corpora, claiming that both entities privilege language learners with convenient access to a variety of natural texts, and the tools to facilitate input comprehension. Whilst these basic features of WELL 2.0 is acknowledged in the existing literature, a number of studies have suggested (at least implicitly) that web 2.0's characteristics have indeed established itself as a distinctive platform to serve the input related initiatives (Godwin-Jones, 2009; Chinnery, 2008; Shei, 2008; Alm, 2006; Lai \& Zhao, 2005).

The first critical aspect of input 2.0 concerns the diversity of web-based contents. Particularly the current web materials are no longer bounded to authority-customised contents but significantly enriched by what Keen (2007) terms the 'cult of the amateur'. This, in turn, leads to a diversity of learning materials that are seen to be potentially more engaging and dynamic for language learners' development of cognitive and social presence (Farmer, 2004; Bruns, 2008). According to Ward (2004), moreover, the exposure of language learners to a plethora of thoughts, questions and links on web 2.0 can enable a development of their interpretative and critical thinking skills.

These positive claims are however rebuked by a number of commentators and linguists who believe that the advocacy of 'diversity' indulges language errors and undermines the quality of online database for language learning (Robb, 2003). As Wu and his colleagues argue pointedly,

"Web contents are heterogeneous in the extreme, uncontrolled and hence 'dirty'... This represents a rather serious constraint of its (web's) use for language learners, because a fundamental requirement for such texts is that they represent exemplary models of language".

(Wu et al., 2009, p, 249-252)

Wu makes a strong argument, which seems to render web 2.0 as a dangerous pitfall for those who in search of learning resources. Yet the hybrid of opportunities and challenges embodied in web-based content has prompted a fundamental question as to what constitute legitimate inputs for language learners with varied initiatives and agendas. Particularly the problems and subversions associated with the input diversity might be disputed by sceptics but well perceived by language learners who take what is considered helpful from the package to address their immediate interests and concerns. For example, if motivation is set as the learning objective, should the engaging materials with a few spelling mistakes still be considered inappropriate? This input puzzle has indeed unfolded a general lack of empirical research on the reality of learners' perceptions and experiences relating to online materials, the insights of which can improve our understanding of the strengths and limits of web 2.0 as a language corpus. 
Secondly, linked with the notion of 'data on an epic scale', RSS is believed to hold promises for the organizations of web 2.0 resources. It is understandable that some commentators feared that the continuation of 'datafication' is turning web 2.0 into a chaotic space where language learners are suffocated by what Benito-Ruiz (2009) terms 'infoxication 2.0'. Here the inconsistency and massive volume of web 2.0 resources are seen as the 'obstacle' and 'barrage' for language learners to locate useful knowledge. The 'basic Boolean searches' empowering WELL 1.0 is seen as inadequate to deal with the worsened information overload that challenges WELL 2.0. In this sense, Benito-Ruiz (2009) suggests that RSS might be the remedy to the diagnosed problem, since language learners can use it to locate and collect the intended resources in just one place. As such, the potential of RSS for input management seems to be intimately linked with the learning orientations and behaviours of language learners. To date, however, there has been little empirical evidence pointing this way.

Moreover, podcasting has been perceived as the 'transformational force' for language teaching and learning (Travis \& Joseph, 2009, p., 313). In particular, podcasts have incorporated authenticity and diversity into the repertoire of listening inputs and, when combined with mobile technologies, created and enhanced opportunities for ubiquitous language learning. As Hegelheimer and O’Bryan (2009) notes,

"Podcasts offer language learners an opportunity to learn from traditional and non-traditional 'teacher' and interact with input on a variety of topics using different varieties of language (e.g. dialects, registers) in a mobile format" (p., 313).

Finally, web 2.0 is said to lend itself to easy and quick search of input explanations so as to modify or clarify the input information, thus increasing its possibility of being processed and internalized (Lai \& Zhao, 2005). Input modification, according to Chapelle (2003), is "the provision of an accessible rendition of the L2 (second language) input" (2003, p., 45). Consistent with this concept, online language samples are often affiliated with elaborated information, annotations, or visual presentations through hyperlinks or RSS. Moreover, there are a myriad of online resources in which language learners can negotiate meanings and socialize in the target language (Benito-Ruiz, 2009). These efforts have clearly created a necessary condition for SLA, not least because the input is made more comprehensible through learner explorations and social interactions.

In summary, WELL 2.0 with its underlying metaphors and affordances is arguably seen as an excellent input depository for language learners. On the bright side, it accommodates a variety of language learning materials, facilitates meaning negotiations and enables seamless interactions between learners and input materials. As a result, WELL 2.0 has been said to have enriched and enhanced the component of input, while simultaneously promoting the concept of learner-centeredness. However, there are opposing voices to most of these assumptions. In order to clarify the divergence, as recurring throughout this subsection, an exploration of learner perceptions and behaviours towards WELL 2.0 seems both important and necessary.

\subsection{Outputs and WELL 2.0}

Not surprisingly, it is believed that the read/write web can amplify and extend the opportunities of learner output owing to its capacity for online publishing, sharing and creative production. Nevertheless, it is noticeable that the notion of learner production is not entirely new to CALL activities in general, especially when e-mail and chat, the most traditional CMC genres, have already engaged language learners as content creators in an authentic communicative environment, and demonstrated the application of pedagogies that reduce learner anxiety and encourage learner expressions (Holliday, 2007; Levy \& Stockwell, 2006; Chapelle, 2003; Sun, 2009). Yet, it has been argued by WELL 2.0 proponents that web 2.0 offers a number of new possibilities, services and advantages that are previously unattainable in CMC (Ullrich, et al., 2008).

As a progress from earlier practices, Wikipedia, being a prominent example of web 2.0, could be argued to effectively promote mindful planning and engagements of language learners. In particular, Wikipedia does not limit itself to the affordance of planning time, but has produced a community that sets expectations for linguistically correct and formal contributions, as evident in Elia (2006)'s conclusion that the content of Wikipedia "shows a formal and standardized style similar to that found in Britannica" (2006, p., 18). This 'community of practice' enables language learners to carefully prepare and edit their linguistic production according to the community standards, thus at the conceptual level leading to the actual behaviour of planning.

Another particularly relevant example for output 2.0 is presented by blogging, the architecture of which is seen to differ from the first generation of asynchronous technologies in several aspects. First of all, blogs are said to break the traditional pattern of 'gated communities' and utterly embrace the 'openness' of readership, hence creating a greater sense amongst bloggers of the variety of potential audiences they can reach (Bloch, 2007; Warschauer \& Grimes, 2007; Lowe \& William, 2004). According to Lee (2010), this awareness of possible readers or listeners enhances the motivation for linguistic production and encourages the uptakes of output 
opportunities presented in the blogosphere. Secondly, Huffaker (2004) notes that the enhanced motivation is also attributed to the availability of both personal and public spaces in blogging communities. This assertion is echoed by Ullrich and his colleagues (2008), who have utilized micro-blogs as a vehicle to accommodate linguistic outputs for extrovert as well as shy and timid language learners. Finally, the archiving of blog entries has been perceived to facilitate learners' reflection on their learning progress (Richardson, 2006). Oladi (2005) suggests in this sense that the self-assessment, if showing development over time, can help achieve greater confidence, which yields resultative motivation on the part of language learners.

Also of interest to language professionals is web's technological advancements of online editing/composition tools. This is because error correction has long been studied and discussed in terms of its ability to flag learners' attention and enable them to critically evaluate their language errors (Chapelle, 2003). Current online editing tools vary in their affordances, but most offer free services of basic grammar and spelling checks, and have progressed to reside themselves on a Web browser, rather than the desktops. In other words, the web 2.0 editing tools have inherited the traditional value of output correction and in addition reinforced their applicability with the flexibility to suit the physical convenience of individuals. As Godwin-Jones (2008) speculates in his discussion concerning what he terms 'web-writing 2.0',

"Browser-based text editors make it easier than ever to participate in online sites. Language tools and services offer an automatic assessment of writing, enabling the development of reviewing skills, so essential to improve writing."

(Godwin-Jones, 2008, p., 7)

Other aspects of output 2.0 have been closely linked with new technologies that open up opportunities and incentives or oral practices. In particular, Stanley (2006) already encourage language learners to produce and podcast their oral output; Rosell-Aguilar (2007) proposes to use podcasts to increase the opportunity for oral practices and monitor the performance of language learners; Sun (2009) uses voice blogs to enhance the oral proficiency of language learners via providing additional opportunities to produce oral output. All these practices indeed chime with the SLA pedagogy that "speaking is improved by practice speaking - in a variety of situational contexts and on a range of topics with diverse socio-pragmatic requirements" (Payne \& Ross, 2005, p., $35)$.

In summary, serving as a basis for understanding WELL 2.0's differential contributions to the output component, the underlying mechanism and technological affordances of web 2.0 have been perceived to not only increase and enhance the availability of output opportunities, or make possible multimedia outputs, but also encourage the actual behaviours of planning, self-assessment and linguistic production, thus facilitating the acquisition process in general.

It is however worth noting that although the literature on output 2.0 is beginning to surface, publications to date mostly focus on a set of services such as blogs, Wikipedia and podcasts, the ones that are perceived to bear significance for learner production. In other words, much attention has been directed at what language learners can and should do with online applications. As a result, little is known about language learners' tendencies, selections and preferences when they unlimitedly interact with the web to produce the target language. This, alarmingly, leads to a bounded understanding of web 2.0's affordance for learner output.

\subsection{Interaction and WELL 2.0}

The emergence of new modes under the rubric of web 2.0 is said to precipitate changes to the communicative uses of the Internet, and thus offering enriching possibilities to language learning (Warschauer \& Grimes, 2008). Indeed, it is believed that the new interactive patterns, while maintaining the 'gains' of traditional CMC, present genuine solutions to some of previously identified limitations. First, there is a potential for online services exemplified by blogs and SNS to temper harsh feedback and discourage unpleasant conversations. Black (2005) exploited the interactive pattern on a social network sites dedicated to fiction writing and sharing in English, and noted that the social feedback on these sites is both supportive and valuable to the development of non-natives' English language skills. Moreover, it could be argued that what Sykes and her colleagues (2008) have envisioned as the 'highly personal' nature of blogs and SNS, coupled with the availability of multimedia presentations, can reduce the probability for anonymity, and thus the tendency for verbal attacks.

In addition, the interactive pattern of networked communities is often found to support collaborative scaffolding and efforts for language learning. Lee (2009) concluded from her intercultural exchange study that group blogs could foster online communities in which language learners can work collaboratively to share and exchange cultural as well as linguistic knowledge. The collaborative merits of online services, according to Sykes and her 
colleagues (2008), are further extended when voice applications are simultaneously put into use. To take an example, Sykes and her colleagues (2008) described a wiki research project involving American learners of Spanish, and presumed that the adoption of web-based voice services as an addition to negotiate ideas and discuss linguistic concerns would "enable collaborative engagement on a more complex level" (Sykes et al., 2008, p., 532).

Concomitant with the massive uptake of multimedia sharing and exchange comes the increased level of accountability for language learners (Oskoz \& Elola, 2010). Specifically, multimedia enhanced interaction can be depicted as a middle space situated someplace between traditional CMC and naturally occurring communication owing to its embedded vocal and visual elements. The blurring of lines between mediated and non-mediated interaction in turn signifies a multitude of means for language learners to engage with authentic online communication, as evident on YouTube, a video sharing website where user communications are either text- or video- based. As Sykes and her colleagues (2008) speculates, "they (text and multimedia production) have the potential to encourage awareness of the use of written language and visual expression as forms of representation that are rooted in, often pluralistic, linguistic and cultural conventions" (p., 530).

Lastly, in contrast with first generation $\mathrm{CMC}$ where many-to-many interactions for learning initiatives are often teacher-led or project-based, and facilitated through computers, WELL 2.0 is seen to provide both the opportunity to interact with and in an open community at learners' choices of time and place, and the propensity for such practices, given that many-to-many communications and mobile technologies have indeed become ingrained in our social lives (Chinnery, 2006; Thorne \& Payne, 2005; Warschauer \& Grimes, 2008). In other words, beyond the walls of standard classroom, there is now a plethora of opportunities for language learners to initiate, direct and manage their interactions with potential interlocutors, through online communities that are open to all who desire to participate. Interaction of this type, as discussed before, is traditionally seen to open a window into the target culture and an access to communicating with native speakers (Ducate \& Lomicka, 2008).

Simply put, as all these examples suggest, the massive and ubiquitous online socialisation is opening doors to self-initiated interactions for the benefit of language and intercultural learning, and has the potentials to support these social processes in a distinctive manner. However, the availability of affordances and communication opportunities does not automatically equal acceptance and quality of interaction on the part of learners. As Felix (2003) observes,

"(in some cases) collaborative online learning has suffered a similar fate to some ill-conceived learning events, in which the process consists of no more than 'communicating' and the outcome of 'having communicated"' (p., $8)$.

The need remains, therefore, to examine language learners' substantial uses of social web tools, and, from this premise, think a little more deeply about the learner-favoured approaches to language learning — what exactly are these tools; why are they chosen; how and to what extent do they promote social interaction that can result in language development? By so doing we can make sense and extend our current understanding towards the potentials as well as limitations and boundaries of the social web in terms of facilitating autonomous interaction.

\subsection{Learning Environment in WELL 2.0}

The common wisdom implying that if one is to learn a language, she should go to the place where the language is spoken somehow corroborates the potential benefits of online environment in terms of immersing learners into the target language and culture, especially for those of EFL (English as a Foreign Language), not least because English has, until recently, been established as the lingua franca of the Internet (Danet \& Herring, 2003). The theoretical underpinnings of such immersion can be found in 'comprehensible input', which accentuates the primary importance of language exposure and believes that language can be comprehended even if learners are uncertain about inputs' linguistic forms (Chapelle, 2003). In this sense, it seems legitimate to assume that the mere browse of and engagement with the current web might lead to some kind of language development, given that learners are, for example, surrounded by newsletters, communities and speakers of the target language without physically being in that country. As such, there seems to be a noteworthy shift from the traditional perception of the web as a tool of retrieving input materials to a new perspective declaring the web as an authentic environment for language learning.

Yet, notwithstanding the aforementioned 'common sense', Gardner (1985) has identified a constellation of social inhibitors that undermine SLA motivation and that consequently impede language learners' linguistic developments even in the target language society. Likewise, if we see the web as an authentic learning environment, it could be argued that the web-based experiences are limited or enhanced in terms of the extent to which it can motivate and involve language learners to mindfully engage with the cognitive and communicative 
opportunities at hand.

Alm $(2006,2009)$ applied the notion of self-determination theory and claimed that the online environment has the potential to support three basic factors reflecting the natural human inclinations and needs, and therefore nurtures, supports and enhances the intrinsic motivation for SLA. He argued that the contents and structures of web 2.0 applications constituted a motivating learning environment in the way that they connected individuals (relatedness), boasted sufficient learning resources that customised learners' individual needs (competence), and provided timely feedback (autonomy). Alm (2006) accordingly launched a WELL 2.0 project, which required language learners to collaboratively produce and share a target language scripted soap opera through wikis, YouTube and social networking sites. Whilst the finding of this study has been entirely encouraging, it failed to show that the compelling learner experiences were directly associated with the web environment, rather than the design of the task per se.

From the individual dimension, Godwin-Jones (2009) speculates that "the Web site (is) becoming what is often referred to as a Personal Learning Environment (PLE)", thereby holding great potentials for learner-centred approach to language learning (p., 3). In particular, he listed a group of services (Table 4) and claimed that online integrators such as iGoogle and Netvibes allow individual 'mash-ups' of these tools on the webpage, thus resulting a PLE that put together a variety of personalized options pertaining to language use: "writing in different contexts/registers, practicing speaking and listening, and reading short, peer posts as well as longer native speaker texts" (p., 5).

Other proponents of PLEs often exemplify what Thorne and Payne (2005) described as "I, I, me-me-me" environments associated with blogging. The individual authoring environments are particularly intriguing to language professionals because they seem to be a place where thoughtful expressions are provoked by the sense of responsibility and ownership (Murray \& Hourigan, 2006; Godwin-Jones, 2003). WELL practitioners accordingly blended blogging service into various initiatives and celebrated, for example, that blog is 'a pathway' to academic writing and 'an additional opportunity' for oral expressions (Bloch, 2007; Sun, 2009). However, it could be argued that these adapted blogging tasks take PLE away from the learners as they centre around the prefabricated agendas of the researcher, rather than to serve the needs and individual efforts of language learners.

\subsection{Differentiation of Learning}

The edge of WELL 2.0 in appealing to learner autonomy and proffering personalized learning opportunities is perceived to accommodate the learner variables identified in the existing literature, thereby facilitating the overall process of SLA (Lai \& Zhao, 2005). In particular, compared to prior CALL stages, WELL 2.0 is seen as a revolution in terms of learner empowerment, because, as Halvorsen (2009) claims, "autonomy is an integral part of what web 2.0 technologies represent" (p., 247).

The web 2.0 package is seen to entail the freedom to store, mash-up, and share information, the privilege to voice individual opinions through a variety of channels, as well as possibilities for interaction, collaboration and community-building. For language learners, the act of content creating, sharing and negotiating is particularly conducive for their development of autonomy and independence. This insight has led many educationalists to believe that WELL 2.0 incorporated and advanced the concept of learner autonomy into the process of language learning. One of the consequences is that language learners are actively involved in the online SLA opportunities, which are understood to be more in tune with their individual aptitude, style, interests and needs (Lai \& Zhao, 2005). It is pointed out that the learner-focused nature of WELL 2.0 can also promote SLA motivation, as language learners have developed a personally meaningful relation to the content of their learning (Ducate \& Lomicka, 2005). Hata (2003) notes further that learner autonomy can ideally result in a greater achievement.

For some sceptics, however, the idea that WELL 2.0 observes the principle of learner autonomy is somehow misleading and fallacious. This is because language learners are not necessarily competent to evaluate their learning process, and thus often need assistance and guidance. Yet the balance between structure and choice does not seem to be well supported in the scenarios of WELL 2.0. For example, of web 2.0 resources Rosell-Aguilar (2007) observes:

"Much of the material is not organized in any obvious way in the directories and it is only after downloading that users can check level and content. In most cases there are no available suggestions about how to use the materials, syllabi, or statements of objectives, either in general or for the individual episode." (Rosell-Aguilar 2007, p., 484)

Additionally, Godwin-Jones (2019) notes that the excessive choices inherit in web 2.0 can be problematic for 
language learners who might not be aware of the available options and the reliability of these learning opportunities. He argues a necessity to teach using technology and build up towards autonomy with initially not autonomous learners. Yet the question is, how can we balance the autonomy promoting with autonomy restricting in the case of teacher mediation?

In fact, whatever claims made in the line of learner autonomy are questionable unless they have been levelled against the learners' subjective needs, perceptions and behaviours. Regardless, the large bodies of support and criticism have at most focused on the web 2.0 per se and the assumptions of learner's readiness to 'take control'. Few have linked themselves to the reality of self-directed WELL 2.0. That is, WELL 2.0 proponents and sceptics have asserted about the control power handing over to language learners while at the same time not testing their responses. It would seem that WELL 2.0 has been a subject of much speculation but little rigorous examinations.

\section{Conclusion}

As said at the outset of this paper, its purpose was to explore the innovative potential of the 'new' WELL 2.0. Bearing with this initiative, this paper has reviewed the development and prospects of using technology for language learning, with the salient components of SLA serving to frame the multifaceted analysis. Drawing these threads together, the connections between the identified components and technological affordances in a long line of developments have been summarized and laid out in Table 2.

Table 2. Connections between the components of SLA and technological affordances in a long line of developments

\begin{tabular}{|c|c|c|c|}
\hline & Pre-networked CALL & Web 1.0 enhanced language learning & Web 2.0 enhance language learning \\
\hline Input & $\begin{array}{l}\text { Instruction/grammatical } \\
\text { explanation }\end{array}$ & $\begin{array}{l}\text { Search engines, authentic learning } \\
\text { resources, multimedia resources, }\end{array}$ & $\begin{array}{l}\text { RSS, podcast, input sharing and } \\
\text { archiving, mash-up, 'user generated } \\
\text { content' as input }\end{array}$ \\
\hline Output & Drill-practices & $\begin{array}{l}\text { Opportunities for authentic } \\
\text { language, planning }\end{array}$ & $\begin{array}{l}\text { Online publishing, communities of } \\
\text { practices, content reproduction, } \\
\text { output editing, collaborative output }\end{array}$ \\
\hline Interaction & $\begin{array}{l}\text { Between people and } \\
\text { computer, between } \\
\text { people when working } \\
\text { together at one computer }\end{array}$ & $\begin{array}{l}\text { One-to-one interaction with } \\
\text { geographically dispersed } \\
\text { individuals, many-to-many } \\
\text { communication within gated } \\
\text { communities }\end{array}$ & $\begin{array}{l}\text { Multimedia interaction, } \\
\text { many-to-many communication with } \\
\text { open communities, online } \\
\text { collaboration, social networking }\end{array}$ \\
\hline $\begin{array}{l}\text { Language } \\
\text { learning } \\
\text { environment }\end{array}$ & $\begin{array}{l}\text { Non-threatening } \\
\text { environment }\end{array}$ & $\begin{array}{l}\text { Authentic communication } \\
\text { environment }\end{array}$ & $\begin{array}{l}\text { Individual authoring environment, } \\
\text { personal learning environment, } \\
\text { enhanced authentic learning } \\
\text { environment }\end{array}$ \\
\hline $\begin{array}{l}\text { Individual } \\
\text { differences }\end{array}$ & $\begin{array}{l}\text { In the language lab, } \\
\text { working at individual } \\
\text { pace }\end{array}$ & In and after class, input selection & $\begin{array}{l}\text { Free of physical constraints; learner } \\
\text { autonomy; individualized learning } \\
\text { opportunity }\end{array}$ \\
\hline
\end{tabular}

The condensed overview of 'the potential of technology for language learning' encompasses increasingly new possibilities and paradigms, while there is an overall tendency for enhanced empowerment, social interaction and participation. The role of technology seems to have evolved from providing the tutorial natured exercises and explanations, via a tool for input obtainments and communication, to a context enabling new forms of interactions, productions and the input manipulations to its broadest sense. The developmental line of tutor-tool-context has somehow explained the much-celebrated 'superiority' of WELL 2.0 - it allows and encourages language learners to assume learning responsibilities through manipulating web 2.0 resources, authoring and sharing online contents, socialising and forming discourse communities. These promises allegedly corroborate principles of socio-cultural SLA where the active role of cognizing subject is accentuated and language learning is seen as an internalisation of social mediation between the learner and a context of learning (Luckin, 2007; Vygotsky, 1978). As such, the Internet now is heralded as a platform catering to the varying initiatives and attitudes of individual learners and it follows, where the forte of WELL 2.0 to be.

However, as illustrated throughout this paper, the discussions and studies surrounding WELL 2.0 were often initiated from the premise of personal belief and opinions, rather than the empirical reasoning associated with the reality of learner experiences (e.g. Lai \& Zhao, 2005; Rosell-Aguilar, 2007; Warschauer \& Grimes, 2008; 
Godwin-Jones, 2008; Wu et al., 2009; Halvorsen, 2008; Murray, 2005). In fact, as with all of the issues addressed, WELL 2.0 seems to be a topic amassed with hyperbole, potentiality, and at best realistic possibilities - reminding us of the need to 'reconsidering the expectations of social web' for language learning (Selwyn, 2009, p., 5).

As educationalists and practitioners alike are assuming an inextricable link between WELL 2.0 and SLA, there surfaces a need to extend the partial accounts of WELL 2.0 and consider closely how learners are perceiving and engaging with WELL 2.0. By so doing we can identify the roles that web 2.0 may actually play in language learning, adding to both our theoretical and empirical understanding of WELL 2.0's prospects as well as boundaries and limitations. As such, we have made the case to move beyond speculations and work towards the meaningful and rigorous examination on the often compromised realities of WELL 2.0.

\section{References}

Ahmad, K., Corbett, G., Rodgers, M., \& Sussex, R. (1985). Computers, language learning and language teaching. Cambridge: Cambridge University Press.

Alm, A. (2006). CALL for autonomy, competence and relatedness: Motivating language learning environments in Web 2.0. The JALT CALL Journal, 2(3), 29-38. https://doi.org/10.29140/jaltcall.v2n3.30

Alm, A. (2009). Blogging for self-determination with L2 learner Journals. In M. Thomas (Ed.), Handbook of research on Web 2.0 and second language learning. https://doi.org/10.4018/978-1-60566-190-2.ch011

Bax, S. (2003). CALL-past, present and future. System, 31(1), 13-28. https://doi.org/10.1016/S0346-251X(02)00071-4

Beauvois, M. H. (1997). Computer-mediated communication (CMC): Technology for improving speaking and writing. In R. M. Terry (Ed.), Technology enhanced language learning, 165-184. Lincolnwood, IL: The National Textbook Company.

Benito-Ruiz, E. (2009). Infoxication 2.0. In M. Thomas (Eds.), Handbook of research on Web 2.0 and second language learning. https://doi.org/10.4018/978-1-60566-190-2.ch004

Black, R. W. (2008). Adolescents and online fan fiction. New York: Peter Lang.

Bloch, J. (2007). Abdullah's blogging: A generation 1.5 student enters the blogosphere. Language Learning \& Technology, 8(3), 66-82.

Brennan, S. E. (1990). Conversation as direct manipulation: an iconoclastic view. In B. Laurel (Ed.), The art of human-computer interface design, 393-404. Reading, MA: Addison-Wesley.

Bruns, A. (2008). Blogs, Wikipedia, Second Life, and beyond: From production to produsage. New York: Peter Lang Publishing.

Chapelle, C. (2003). English language learning and technology. John Benjamins, Amsterdam. https://doi.org/10.1075/11lt.7

Chinnery, G. (2006). Emerging technologies--Going to the MALL: Mobile assisted language learning. Language Learning \& Technology, 10(1), 9-16.

Chinnery, G. (2008). You've got some GALL: Google-assisted language learning. Language Learning and Technology, 12(1), 3-11.

Coleman, J. A. (2000). Study abroad. In Byram (Ed.), 582-584.

Cotterall, S. (1995). Readiness for autonomy: investigating learner belief. System, 23(2), 195-205. https://doi.org/10.1016/0346-251X(95)00008-8

Cummins, J., \& Sayers, D. (1990). Education 2001: Learning networks and educational reform. Computers in the schools, 7, 1-29. https://doi.org/10.1300/J025v07n01_01

Danet, B., \& Herring, S. (2003). Introduction: the multilingual Internet. JCMC, 9(1). https://doi.org/10.1111/j.1083-6101.2003.tb00354.x

Davies, G. (n.d.). ICT4LT Module, 1.5: Introduction to the Internet. In Information and Communication Technologies for Language Teachers (Modules in English). Retrieved from http://www.ict4lt.org/en

Ducate, L., \& Lomicka, L. (2008). Adventures in the blogosphere: from blog readers to blog writers. Computer Assisted Language Learning, 21(1), 9-28. https://doi.org/10.1080/09588220701865474

Egan, K. B. (1999). Speaking: A critical skill and a challenge. CALICO journal, 16(3), 277-293. 
Egbert, J., \& Hanson-Smith, E. (1999). Computer-enhanced language learning environments: an overview. In J. Egbert \& E. Hanson-Smith (Eds.), CALL environments: research, practice and critical issues. TESOL Inc, Alexandria, VA, 1-13.

Elia, A. (2007). An analysis of Wikipedia digital writing. Retrieved from http://www.sics.se/jussi/Artiklar/2006_NewText_Trento/Proceedings/working_notes/04_elia_new.pdf

Ellis, R. (1997). Second Language Acquisition. Oxford: Oxford University Press.

Farmer, J. (2004). Communication dynamics: Discussion boards, weblogs, and the development of communities of inquiry in online learning environments. Retrieved from http://incsub.org/blog/2004/communication-dynamics-discussion-boards-weblogs-and-the-development-ofcommunities-of-inquiry-in-online-learning-environments

Felix, U. (2003). Language learning online: towards best practice. London: Routledge.

Gardner, R. C. (1985). Social psychology and second language learning: the role of attitudes and motivation. Baltimore: E. Arnold.

Godwin-Jones, R. (2003). Emerging technologies: Blogs and wikis: Environments for online collaboration. Language Learning \& Technology, 7(2), 12-16.

Godwin-Jones, R. (2008). Emerging technologies: Web-writing 2.0: Enabling, documenting, and assessing writing online. Language Learning \& Technology, 12(2), 7-13.

Godwin-Jones, R. (2009). Emerging technologies: Personal learning environments. Language Learning \& Technology, 13(2), 3-9.

Godwin-Jones, R. (2019). Riding the digital wilds: Learner autonomy and informal language learning. Language Learning \& Technology, 23(1), 8-25. https://doi.org/10125/44667

Gonzalez-Edfelt, N. (1990). Oral interaction and collaboration at the computer: Learning English as a second language with the help of your peers. Computers in the Schools, 7(1/2), 53-90. https://doi.org/10.1300/J025v07n01_03

Halvorsen, A. (2009). Social Networking Sites and Critical Language Learning. In M. Thomas (Ed.), Handbook of research on Web 2.0 and second language learning. https://doi.org/10.4018/978-1-60566-190-2.ch013

Hanson-Smith, E. (2001). Computer-assisted language learning. In R. Carter \& D. Nunan (Eds.), The Cambridge guide to teaching English to speakers of other languages, 107-113. Cambridge: Cambridge University Press. https://doi.org/10.1017/CBO9780511667206.016

Harnad, S. (1991). Post-Gutenberg galaxy: The fourth revolution in the means of production and knowledge. Public-Access Computer System Review, 2, 39-53.

Harrington, M., \& Levy, M. (2001). CALL begins with a "C": Interaction in computer-mediated language learning. System, 29, 15-26. https://doi.org/10.1016/S0346-251X(00)00043-9

Hata, M. (2003). Literature review: Using computer-mediated communication in second language classroom. Osaka Keidai Ronshu, 54(3), 115-125.

Hegelheimer, V., \& O’ Bryan, A. (2009). Mobile technologies, podcasting and language education. In M. Thomas (Eds.), Handbook of research on Web 2.0 and second language learning. https://doi.org/10.4018/978-1-60566-190-2.ch018

Herring, S. (1996). Computer mediated communication: Linguistic, social and cross-cultural perspectives. John Benjamins, Amsterdam. https://doi.org/10.1075/pbns.39

Holec, H. (1981). Autonomy and foreign language learning. Oxford: Pergamon.

Holland, V., M., Kaplan, J. D., \& Sabol, M. A. (1999). Preliminary tests of language learning in a speech-interactive graphics microworld. CALICO Journal, 17(3), 395-430.

Holliday, A. (2007). Response to ELT and "the spirit of the times". ELT Journal, 61(4), 360-366. https://doi.org/10.1093/elt/ccm054

Hoven, D. (1997). Instructional design for multimedia: Towards a learner-centered CELL (Computer-Enhanced Language Learning) model. In K. A. Murphy-Judy (Ed.), NEXUS: The convergence of language teaching and research using technology, 98-111. Durham, NC: CALICO. 
Hoven, D. (1999). A model for listening and viewing comprehension in multimedia environments. Language Learning \& Technologies, 3(1), 88-103.

Huffaker, D. (2004). The educated blogger: Using weblogs to promote literacy in the classroom. First Monday, 9(6). https://doi.org/10.5210/fm.v9i6.1156

Jonassen, D. (1992). What are cognitive tools? In P. A. M. Kommers, D. H. Jonassen \& J. T. Mayes (Eds.), Cognitive tools for learning, 1-6. Berlin: Springer-Verlag. https://doi.org/10.1007/978-3-642-77222-1_1

Keen, A. (2007). The cult of the amateur. New York: The Crown Publishing Group.

Kelm. O. R. (1998). The use of electronic mail in foreign language class. In K. Arens (Ed.), Language learning online, 141-154. Austin, TX: The Daedalus Group Inc.

Kern, R., \& Warschauer, M. (2000). Networked-based language teaching: Concepts and practices. Cambridge: Cambridge University Press. https://doi.org/10.1017/CBO9781139524735

Kern, R. (1996). Computer-mediated communication: Using e-mail exchanges to explore personal histories in two cultures. In M. Warschauer (Ed.), Telecollaboration in foreign language learning, 105-119. Honolulu, HI: University of Hawai'i, Second Language Teaching \& Curriculum Centre.

Lai, C., \& Zhao, Y. (2005). Introduction: The importance of input and the potential of technology for enhancing input. In Y. Zhao (Ed.), Technology and second language learning. Connecticut: Information Age Publishing.

Lantolf, P., \& Appel, G. (1994). Theoretical framework: an introduction to Vygotskian perspectives and on second language research. In P. Landolf \& G. Appel (Eds.), Vygotskian approaches to second language research. Ablex, Norwood, NJ, 1-32.

LaRocca, S. A., Morgan, J. J., \& Bellinger, S. M. (1999). On the path to 2X learning: Exploring the possibilities of advanced speech recognition. CALICO Journal, 16(3), 295-309.

Lee, L. (2009). Promoting intercultural exchanges with blogs and podcastings: A study of Spanish-American telecollaboration. Computer Assisted Language Learning, 22(5), 425-443. https://doi.org/10.1080/09588220903345184

Lee, L. (2010). Fostering reflective writing and interactive exchange through blogging in an advanced language course. ReCALL, 22(2), 212-227. https://doi.org/10.1017/S095834401000008X

Levy, M., \& Stockwell, G. (2006). CALL dimensions: Options and issues in computer-assisted language learning. New Jersey: Lawrence Frlbaum Associates, Inc.

Levy, M. (1997). Computer-assisted language learning: Context and conceptualization. New York: Oxford University Press.

Little, D. (2001). Learner autonomy and the challenge of tandem language learning via the Internet. In A. Chambers \& G. Davies, (Eds.), 29-38.

Liu, M., \& Reed, W. M. (1995). The effect of hypermedia-assisted-instruction on second language learning. Journal of Educational Computing Research, $12(2), \quad$ 159-175. https://doi.org/10.2190/3161-M47F-GVAM-B38K

Liu, M., Moore, Z., Graham, L., \& Lee, S. (2000). A look at the research on computer-based technology use in second language learning: review of literature from 1990-2000. Journal of Research on Technology in Education. Retrieved from http://jabba.edb.utexas.edu/it/seclangtechrev.pdf

Lowe, C., \& William, T. (2004). Moving to the public: Weblogs in the writing classroom. In L. Gurak, S. Antonijevic, L. Johnson, C. Ratliff \& J. Reyman (Eds.), Into the blogosphere: Rhetoric, community, and culture of weblogs. from http://blog.lib.umn.edu/blogosphere/blogging_as_social_action_a_genre_analysis_of_the_weblog.html

Luckin, R. (2008). The learner centric ecology of resources: a framework for using technology to scaffold learning. Computers \& Education, 50, 449-462. https://doi.org/10.1016/j.compedu.2007.09.018

Meskill, C., \& Rangelova, K. (1995). U.S. language through literature: A transatlantic research project. In M. Warschauer (Ed.), Virtual connections: Online activities and projects for networking language learners, 134-136. Honolulu, HI: University of Hawai'i, Second Language Teaching \& Curriculum Centre.

Moran, C. (1991). We write, but do we read? Computers and Composition, 8, 51-61. 
Myers, G. (2010). The discourse of blogs and wikis. New York: Continuum International Publishing Group.

Oladi, S. (2005). Study of Tehran medical students' social interaction in cyber blogging environment and its effect on IELTS writing proficiency.

Oskoz, A., \& Elola, I. (2010) Meeting at the wiki: The new arena for collaborative writing in foreign language courses. In M. Lee \& C. McLoughlin (Eds.), Web 2.0-based e-learning: Applying social informatics for tertiary teaching. Hershey PA: IGI Global.

Oxford, R. (1994). Where are we regarding language learning motivation? The Modern Language Journal, 78(4), 512-514. https://doi.org/10.1111/j.1540-4781.1994.tb02069.x

Payne, J. S., \& Ross, B. M. (2005). Synchronous CMC, working memory, and L2 oral proficiency development. Language Learning \& Technology, 9(3), 35-54.

Pellettieri, J. (2000). Negotiation in cyberspace: the role of chatting in the development of grammatical competence. In R. Kern (Ed.), Network-based language teaching: Concepts and practice, 59-86. Cambridge: Cambridge University Press. https://doi.org/10.1017/CBO9781139524735.006

Pennington, M. C. (1996). The power of the computer in language education. In M.C. Pennington (Ed.), The power of CALL, 1-14. Houston, TX: Athelstan.

Peyton, J. K. (1999). Theory and research: Interactive via computers. In J. Egbert \& E. Hanson-Smith (Eds.), 17-26.

Richardson, W. (2006). Blogs, wikis, podcasts, and other powerful Web tools for classrooms. Thousand Oaks, CA: Corwin Press.

Robb, T. (2003). Google as a quick 'n dirty corpus tool. TESL, EJ, 7(2). Retrieved from http://www.tesl-ej.org/wordpress/issues/volume7/ej26/ej26int/

Rosell-Aguilar, F. (2007). Top of the pods-In search of a podcasting "podagogy" for language learning. Computer Assisted Language Learning, 20(5), 471-492. https://doi.org/10.1080/09588220701746047

Ruschoff, B. (2009). Output-oriented language learning with digital media. In M. Thomas (Ed.), Handbook of research on Web 2.0 and second language learning. https://doi.org/10.4018/978-1-60566-190-2.ch003

Salaberry, R. (2000). Pedagogical design of computer mediated communication tasks: learning objectives and technological capabilities. Modern Language Journal, 84(1), 28-37. https://doi.org/10.1111/0026-7902.00050

Salaberry, R. (2001). The use of technology for second language learning and teaching: a retrospective. Modern Language Journal, 85(i), 39-56. https://doi.org/10.1111/0026-7902.00096

Schoelles, M., \& Hamburger, H. (1996). Cognitive tools for language. Computer Assisted Language Learning, 9(2), 213-234. https://doi.org/10.1080/0958822960090210

Schwienhorst, K. (2008). Learner autonomy and CALL environments. Routledge: Taylor \& Francis Group.

Selwyn, N. (2009). Challenging educational expectations of the social web: a web 2.0 far? Nordic Journal of Digital Literacy.

Sheaffer-Jones, C. (2000). Designing a community learning environment using a bulletin board system: a trial with advanced French written communication. In T. Lewis \& A. Rouxeville (Eds.) Technology and the advanced language learner, 108-124. London: Centre for Information on Language Teaching and Research.

Shei, C. C. (2008). Discovering the hidden treasure on the Internet: using Google to uncover the veil of phraseology. $\quad$ Computer Assisted Language Learning, 21(1), 67-85. https://doi.org/10.1080/09588220701865516

Skinner, B. F. (1954). The science of learning and the art of teaching. Harvard Educational Review, 24, 86-97.

Skinner, B. F. (1957). Verbal behaviour. New York: Appleton-Century-Crofts. https://doi.org/10.1037/11256-000

Smith, S., \& Sherwood, B. (1976). Educational uses of the PLATO computer system. Science, 192, 344-352. https://doi.org/10.1126/science.769165

Spolsky, B. (1989). Conditions for second language learning: Introduction to a general theory. Oxford: Oxford University Press.

Sproull, L., \& Kiesler, S. (1991). Connections: New ways of working in the networked organization. Cambridge, MA: MIT Press. 
Stanley, G. (2006). Podcasting: Audio on the Internet comes of age. TESL-EJ, 9(4). Retrieved from http://www.teslej.org/wordpress/issues/volume9/ej36/ej36int/

Sturm, M., Kennell, T., McBride, R., \& Kelly, M. (2009). The pedagogical implications of Web 2.0. In M. Thomas (Eds.), Handbook of research on Web 2.0 and second language learning. https://doi.org/10.4018/978-1-60566-190-2.ch020

Sullivan, N., \& Pratt, E. (1996). A comparative study of two ESL writing environment: a computer-assisted classroom and a traditional oral classroom. System, 24(4), 491-501. https://doi.org/10.1016/S0346-251X(96)00044-9

Sun, Y. (2009). Voice blog: an exploratory study of language learning. Language Learning \& Technology, 13(2), 88-103.

Sykes, M. J., Oskoz, A., \& Thorne, S. L. (2008). Web 2.0, synthetic immersive environments, and mobile resources for language education. CALICO Journal, 25(3), 528-546. https://doi.org/10.1558/cj.v25i3.528-546

Travis, P., \& Joseph, F. (2009). Improving Learners' speaking skills with podcasts. In M. Thomas (Eds.), Handbook of research on Web 2.0 and second language learning. https://doi.org/10.4018/978-1-60566-190-2.ch017

Ulitsky, H. (2000). Language learner strategies with technology. Journal of Educational Computing Research, 22(3), 285-322. https://doi.org/10.2190/VLTU-CCXF-NFYL-277H

Ullrich, C., Borau, K., Luo, H., Tan, X., Shen, L., \& Shen, R. (2008). Why web 2.0 is good for learning and for research: principles and prototypes. In International World Wide Web Conference. https://doi.org/10.1145/1367497.1367593

Vilmi, R. (1995). International environment activity. In M. Warschauer (Ed.), Virtual connections: Online activities and projects for networking language learners, 205-207. Honolulu, HI: University of Hawai, Second Language Teaching \& Curriculum Centre.

Vygotsky, L. S. (1978). Mind in society: The development of higher psychological processes. Cambridge, MA: Harvard University Press.

Ward, J. M. (2004). Blog assisted language learning (BALL): Push button publishing for the pupils. TEFL Web Journal, 3(1).

Warschauer, M., \& Grimes, D. (2007). Audience, authorship, and artifact: the emergent semiotics of Web 2.0. Annual Review of Applied Linguistics, 27, 1-23. Cambridge: Cambridge University Press. https://doi.org/10.1017/S0267190508070013

Warschauer, M., \& Healey, D. (1998). Computers and language learning: an overview. Language Teaching, 31, 57-71. https://doi.org/10.1017/S0261444800012970

Warschauer, M. (1996). Computer-assisted language learning: an introduction. In S. Fotos (Ed.), Multimedia language teaching, 3-20. Tokyo: Logos.

Warschauer, M. (1997). Computer-mediated collaborative learning: theory and practice. Modern Language Journal, 81(4), 470-481. https://doi.org/10.1111/j.1540-4781.1997.tb05514.x

Warschauer, M. (1999). Electronic literacies: Language, culture, and power in online education. Mahwah, NJ: Lawrence Erlbaum Associates. https://doi.org/10.4324/9781410604682

Wu, S., Franken, M., \& Witten, H. I. (2009). Refining the use of the web (and web search) as a language teaching and learning resource. Computer Assisted Language Learning, 22(3), 249-268. https://doi.org/10.1080/09588220902920250

Zhao, Y. (2003). Recent developments in technology and language learning: a literature review and meta-analysis. CALICO Journal, 21(1), 7-27. https://doi.org/10.1558/cj.v21i1.7-27

\section{Copyrights}

Copyright for this article is retained by the author(s), with first publication rights granted to the journal.

This is an open-access article distributed under the terms and conditions of the Creative Commons Attribution license (http://creativecommons.org/licenses/by/4.0/). 